\title{
Sundhedspersoners strafansvar for grovere eller gentagen forsømmelse eller skødesløshed ${ }^{12}$
}

\author{
Af Søren Birkeland, overloege, lektor, cand. jur., ph.d., \\ Institut for Regional Sundhedsforskning, Syddansk Universitet
}

\begin{abstract}
The Danish Supreme Court recently passed judgement in the so-called 'Svendborg Case' concerning the treatment of a male diabetic admitted to an emergency room for abdominal pain. The patient developed a severe hypoglycaemia and brain damage, and later died. Referencing para 75 of the Healthcare Authorization Act warranting fines or imprisonment, the prosecuting authority charged a young resident with gross negligence. While the resident was found not guilty, the case prompted a re-examination of the interpretation of para 75. This paper reviews the Svendborg Case and previous case law. When assessing the criminal liability of healthcare professionals, a number of themes emerge including severely inadequate patient examinations, hazardous use of drugs, essential surgical errors ('wrong-side-surgery' etc.) and utilization of perceptibly unlawful interventions. Section 75 seems to apply primarily when individuals diverge substantially from standard healthcare practices. From a more generic criminal law perspective, emphasis is placed upon a situational, manifest, and inexcusable deviation from commonly accepted norms (the 'objective' component; also emphasising repeated deviations). Furthermore, weight is put on the presence of premeditation or a particular degree of carelessness (lack of caution; a 'subjective' component). Finally, there must be a potential for substantial injury with a plausible causal connection to the health professional's action (or inaction), and which in the particular situation should be taken into account ('inter-subjective' component). That said, it must be acknowledged that the boundaries between the aforementioned components are sometimes blurred.
\end{abstract}

1. Tak til professor emeritus Gorm Toftegaard Nielsen for værdifuld diskussion om artiklens tema.

2. Title in English: The criminal liability of healthcare professionals accused of gross negligence. 


\section{Indledning}

I marts 2018 afgjorde Højesteret én af de måske mest spektakulære danske sager om sundhedsprofessionelt strafansvar med frifindelsen af en yngre læge efter idømmelse af bødestraf i Østre Landsret. Sagen affødte stor debat. I den forbindelse blev der i pressen luftet krav om ændring og 'klargøring' af lovgivningen. Der blev af skeptikere bl.a. peget på at frifindelsen ikke vil 'sikre' sundhedspersoner fremadrettet og at læger derfor risikerer at blive dømt for grovere forsømmelse i kommende sager, medmindre »der kommer klarere regler på området« (Hildebrandt, 2018). Tilsvarende blev det fra 'sundhedsjuridisk' side udtalt, at dommen ikke har »den principielle karakter, som man fra loegernes side har ønsket, at den skulle have (Hedegaard, 2018). Imidlertid fik eksempelvis dommens overensstemmelse med teori og hidtidig praksis bemærkelsesværdigt lidt opmærksomhed. I denne artikel gennemgås indholdet af det sundhedsprofessionelle strafansvar med integration af strafferetlig teori og domspraksis.

\section{Autorisationsloven, disciplinæransvar og strafansvar}

I henhold til autorisationsloven (AL; aktuelt bekendtgørelse af lov om autorisation af sundhedspersoner og om sundhedsfaglig virksomhed nr. 1141 af 13. september 2018) skal autoriserede sundhedspersoner udvise »omhu og samvittighedsfuldhed « (§ 17). Bestemmelsen fastlægger i sammenhæng med Sundhedsvæsenets Disciplinærnævns beføjelser i henhold til klage- og erstatningsloven (KEL; aktuelt Bekendtgørelse af lov om klage- og erstatningsadgang inden for sundhedsvæsenet nr. 995 af 14. juni 2018) et disciplinceransvar. Overtrædelser af $\S 17$ påtales af Disciplinærnævnet. Nævnet kan dog oversende sagen til anklagemyndigheden med henblik på evt. straffesag (se forudsætningsvis klage- og erstatningslovens $\S 17$, stk. 3, samt bekendtgørelse nr. 1447 af 15. december 2010 om Forretningsorden for Sundhedsvæsenets Disciplinærnævn, § 3, stk. 2).

Det følger af $\mathrm{AL} \S 75$, at »En autoriseret sundhedsperson, der gør sig skyldig $i$ grovere eller gentagen forsømmelse eller skødesløshed $i$ udøvelsen af sin virksomhed, straffes med bøde eller fangsel i indtil 4 måneder « (§ 75). Sundhedspersoners strafansvar efter $\S 75$ er et domstolsanliggende. I den forudgående lægelovs $\S 18$ fandtes en nærmest ligelydende strafbestemmelse og tilsvarende fandtes i andre autorisationslove. Erstatningsansvar for sundfaglig behandling er adskilt fra disciplinær- og strafansvaret. Man har i Danmark gjort op med tidligere tiders tilstand, hvorefter patienten skulle udtage stævning mod formodet erstatningsansvarlige $\mathrm{i}$ sundhedsvæsenet for derefter at skulle bevise, at der forelå ansvarsgrundlag mv. Sundhedsfagligt erstatningsansvar er siden 1. juli 1992 blevet håndteret i henhold til den særlige patientforsikringsordning, hvorefter der gives pati- 
enter erstatning for skader opstået under behandling mv. i sundhedsvæsenet i videre omfang end efter i øvrigt gældende erstatningsregler og på en for patienten lettere og hurtigere måde (KEL, kapitel 3-4 a). I det følgende gennemgås en række afgørelser efter strafbestemmelsen i AL $\S 75$.

\section{Domstolsafgorelser om sundhedspersoners strafansvar}

Den første domstolsafgørelse i denne gennemgang er U 1981.173 Ø, som omhandlede en læge, der undlod at lade sin bevidsthedssvækkede hustru indlægge umiddelbart, selv om hun havde indtaget sovemidler af den ældre og farlige barbiturattype og efterfølgende blev stadigt dybere bevidstløs. Lægen forklarede i retten, at han i den pågældende situation ikke følte sig som læge, idet han henviste til, at han 'på grund af den følelsesladede situation' ikke var i stand til at være objektiv. Dette kompliceredes af, at hustruen var ansat på det lokale sygehus. For at undgå skandale på sygehuset havde han telefoneret til afdelingssygeplejersken på sygehusets narkoseafdeling, »idet han regnede med, at hun ikke ville fortcelle noget på sygehuset til [hustruens] kolleger«. Afdelingssygeplejersken »kom straks til stede, og sammen holdt de [hustruen] under observation«. Da hustruen efterhånden blev mere bevidsthedsfjern, foranstaltede lægen endeligt hustruen indlagt efter aftale med vagthavende reservelæge. Retslægerådet udtalte i en erklæring, at hustruen »ved indloeggelsestidspunktet var dybt bevidstløs og havde faldende blodtryk, en tilstand, der må karakteriseres som umiddelbart livsfarlig «, samt at lægen »ved at udscette indloeggelsen til dette tidspunkt « havde »medvirket til at øge risikoen $i$ den livsfarlige tilstand, hvor han ikke havde muligheder for adcekvat behandling«, og at lægen derfor havde »udvist forsømmelighed og begået fejl i forbindelse med behandlingen « af hustruen. Byretten henviste i sagen til, at »tiltalte på grund af personlige og følelsesmoessige faktorers indflydelse har voeret mindre egnet til at foretage en saglig og objektiv bedømmelse af situationen«, og frifandt derfor lægen. Østre Landsret fandt derimod, at »tiltalte ved den omhandlede lejlighed har virket som loege«, og idømte lægen en bøde på 5.000 $\mathrm{kr}$. Landsretten fremhæver hermed det princip, at man som autoriseret sundhedsperson i udgangspunktet vil blive vurderet efter autorisationslovens ansvarsbestemmelser, når man udøver sundhedsprofessionel virksomhed. Det bemærkes, at der eksplicit henvises til den særlige situation og tilstanden på tidspunktet for det påståede 'undladelsesdelikt' (manglende indlæggelse), hvorved det situationelle element af strafansvarsvurderingen træder tydeligt frem (sammenlign om erstatningsansvarsvurderingen i 'handlingsøjeblikket' von Eyben \& Isager (2015)). Retslægerådet finder i tiltaltes håndtering både kausalitet, en scerlig uforsigtighed og betydeligt skadespotentiale (jf. 'medvirket til' at 'øge risikoen' i 'den livsfarli- 
ge tilstand'), ligesom rådet ekspliciterer et påregnelighedselement (»tilstand, der må karakteriseres som umiddelbart livsfarlig«)(sammenhold endvidere Waaben (2015)). Normafvigelsen ('retsstridigheden') synes ifølge rådet at bestå i dette at 'udsætte indlæggelsen'. Det forekommer umiddelbart at være en åbenbar (alment konstaterbar) normafvigelse ikke at indlægge en bevidstløs patient, som er forgiftet med livsfarlig sovemedicin. For så vidt hovedelementerne i strafansvarsvurderingen så at sige 'serveres' af rådet, kunne der måske argumenteres for, at én eller flere repræsentanter derfra gav fremmøde i retten, så forskellige vurderinger kunne holdes op imod hverandre, med mulighed for at også forsvaret kunne stille uddybende og kritiske spørgsmål (sammenhold betydningen af den eksterne sagkyndiges nuancering af Rådets vurdering nedenfor i U 1998.1056 V). By- og landsret synes i den konkrete sag især at adressere spørgsmålet om autorisationslovens dækningsområde og evt. undskyldelige omstoendigheder (uenighed mellem by- og landsret). Med hensyn til sagstype handler dommen om scerligt risikabel patienthåndtering med farlig medicin.

En anden type problematik i sager om sundhedsprofessionelt strafansvar er mangelfuld undersøgelse eller tilsyn. U 1983.259 Ø er et eksempel herpå. I sagen havde en natlæge undladt at foretage objektiv, klinisk undersøgelse af en patient, som havde haft krampeanfald. Patienten døde samme dag efter et nyt anfald, formodentlig efter bristende karmisdannelse eller lignende. Den 34-årige mand havde inden vagtlægebesøget haft et "universelt krampeanfald med vedvarende sammentrcekninger af muskler i lemmer og ryg [tillige med] urinafgang «. Patienten havde efter det oplyste været bevidstløs under anfaldet. Ifølge tiltalte var der under sygebesøget »ikke noget uscedvanligt at se« på patienten, og han havde angiveligt spurgt patienten, hvordan han havde det, hvorpå patienten havde svaret "at han havde det meget godt, bortset fra lidt hovedpine«. Tiltalte havde derpå fået »den opfattelse, at der havde foreligget et epileptisk anfald, idet han ikke kunne iagttage følger af mulige andre ting, f.eks. en hjerneblødning «. Endvidere havde patienten angiveligt benægtet, at han tidligere havde haft anfald eller sygdomme af betydning. Efterfølgende havde patienten fulgt vagtlægen til dørs, hvorved vagtlægen angiveligt bemærkede, at der ikke var noget 'unormalt' ved patientens bevægelser. Desuden forklarede lægen, at han under samtalen med patienten i et par meters afstand havde iagttaget patientens pupiller og ikke fundet noget unormalt. Vagtlægen havde opfordret patienten til at opsøge egen læge med henblik på en nærmere undersøgelse. Han angav at have overvejet indlæggelse, men "undlod det, da han ikke havde iagttaget symptomer på blødninger med videre«, hvorfor han også mente, "at en noermere undersøgelse kunne vente«. Om forventningerne til en objektiv undersøgelse anførte Retslægerådet, at 
»Intet enkelt led i den kliniske neurologiske undersøgelse er obligat« [uomgængelig]. Rådet beskrev dog en længere række 'passende' undersøgelser. Vagtlægen blev frifundet i byretten, da denne fandt, at han i henhold til en kredslæge og Retslægerådets vurdering nok 'burde' have foretaget nærmere undersøgelser af patienten, og således havde udvist forsømmelighed, men fandt det 'overvejende betcenkeligt' at tilregne lægen undladelsen af de efter hans skøn unødvendige undersøgelser som grovere forsømmelighed eller skødesløshed. Dommen blev anket til Østre Landsret, som idømte vagtlægen en bøde på $2.000 \mathrm{kr}$. I den forbindelse blev der henvist til Retslægerådets vurdering, at »Såfremt det lagges til grund at tiltalte overhovedet ikke har foretaget en objektiv klinisk undersøgelse omfattende blandt andet flere af de [netop anførte] undersøgelser, samt en undersøgelse af hjertet og en måling af blodtrykket må det efter retslogerådets opfattelse karakteriseres som en grovere forsømmelse«. I landsrettens afgørelse finder man en henvisning til en substantiel og vel for alle mennesker erkendelig afvigelse fra accepterede normer (lægen undersøgte overhovedet ikke patienten efter alvorligt krampeanfald med bevidstløshed), medens især vurderingen i forhold til kausalitet og adækvans i højere grad er implicit.

Atter en type problematik, som har vist sig i sager om sundhedspersoners strafansvar, er operativ fejlintervention. I U 1983.1093 V havde en overlæge fejlagtigt amputeret patientens 3 . finger i stedet for den 4 . finger. Vestre Landsret idømte lægen en bøde på 2.000 kr. Det fremgår af sagsfremstillingen, at overlægen havde læst patientens sygejournal og sammen med patienten set på fingeren $\mathrm{og}$ talt $\mathrm{om}$, at det var den 4 . finger, som skulle opereres. Om operationen fremgår det, at patienten var bedøvet, at hele hånden var jodet ind, og at der ikke var nogen særlig markering af den finger, som skulle opereres. Imidlertid havde overlægen ikke "vvaret $i$ tvivl om, hvilken finger det drejede sig om, og han blev ikke under operationen opmoerksom på, at det var den forkerte finger, idet der også var kredsløbsforstyrrelser i 3. finger, hvor den ene pulsåre var lukket, medens der var lavt tryk $i$ den anden «. Videre fremgår det, at patienten umiddelbart efter operationen gjorde overlægen opmærksom på, at det var den forkerte finger, hvilket overlægen erkendte, ligesom han angiveligt erkendte, at der var begået en fejl. Derpå foretog overlægen efter aftale med patienten amputation af også højre 4. finger. Under hensyn til, at overlægen »kendte patientens sygehistorie og havde loest sygejournalen under morgenkonferencen samt yderligere orienteret sig om operationen ved en samtale med patienten «, fandt byretten ikke, at der forelå omstændigheder af så grov karakter, at forholdet kunne anses for grovere forsømmelse eller skødesløshed. Landsretten nåede til det modsatte resultat. Skadespotentiale såvel som årsagsforbindelse og påregnelighed er i denne sag oplagt. Det 
må konstateres, at landsretten igen i strafansvarsvurderingen lægger vægt på både tilstedeværelsen af en alment konstaterbar normafvigelse (fjernelse af den forkerte finger), tillige med at retten antyder en scerlig mangel på agtpågivenhed (fjernelse af finger »uden forinden at have giort sig klart, hvad der skulle bortopereres«).

Også U 1987.608 omhandlede operativ fejlintervention. I sagen blev en tandlage fundet skyldig i forbindelse med implantationsbehandling af to patienter med henvisning til dagældende tandlægelovs $\S 19$, hvorefter »Den tandlcege, der gør sig skyldig i grovere eller gentagen forsømmelse eller skødesløshed under udøvelsen af sin virksomhed, straffes med bøde eller hoefte«. I det ene tilfælde havde tandlægen negligeret en række klare tegn på fejlslagen implantatbehandling og undladt at fjerne implantatet, hvilket medførte en delvis ødelæggelse af kæbeknoglen. I det andet tilfælde havde han indopereret et implantat i en allerede inficeret kæbeknogle, hvilket umuliggjorde videre implantatbehandling. Tandlægen var allerede straffet med bøde for to lignende tidligere tilfælde, og straffen fastsattes derfor nu til en samlet bødestraf på $100.000 \mathrm{kr}$. med forvandlingsstraf af hæfte i 60 dage (se straffelovens $\S 89$, jf. $\S 88$ ). Der er i domsreferatet ikke megen information om rettens strafansvarsmæssige argumentation, men det må konstateres, at der i sagen beskrives gentagende tilfælde af afvigelser fra, hvad der vel også enkeltvis betragtet kunne erkendes af lægmand som det forsvarlige (indoperere implantat i betændt væv uden opfølgning). Tillige påpeges en særlig mangel på agtpågivenhed (negligeret 'umiskendelige' tegn) samt et skadespotentiale, som er både betydeligt (delvis ødelæggelse af kæbeknoglen) og antages kausalt ('påførte').

U 1991.459 Ø handlede ligesom U 1981.173 om risikabel patienthåndtering ved farlig medicin, men også om mangelfuld undersøgelse (sammenlign $\mathbf{U}$ 1983.259 Ø ovenfor) og ulovlig virksomhed. I sagen blev en læge idømt en bøde på $1.500 \mathrm{kr}$. af Østre Landsret efter at have udskrevet en recept på barbiturat (se ovenfor U 1981.173 Ø), som ifølge Sundhedsstyrelsens bekendtgørelse nr. 510 af 19. november $1985 \S 43$, stk. 1, kun måtte udleveres til sygehuse. Recepten var udskrevet til brorens svoger i forbindelse med alkohol-abstinensbehandling, helt uden at lægen havde undersøgt svogeren. Tiltalte havde forklaret, at »han tidligere havde varet med til at indlogge patienten og diskuteret behandlingen med patientens egen loege«, og at han således havde »såvel en familiemcessig som loegelig baggrund for at vurdere patientens abstinenser«, samt at broderen aktuelt »havde kontaktet ham og bedt om Diemal, idet patienten var rystende, bleg og meget urolig «. Østre Landsret fandt imidlertid at ordination af den omhandlede mængde barbiturat $i$ strid med bekendtgørelsen (§ 43) og uden forudgående un- 
dersøgelse af patienten var en overtrædelse af lægelovens $\S 18$, stk. 1, om 'grovere forsømmelse'. Domsreferatet er ret kortfattet, men der henvises til et specificeret brud på lovgivningen (§ 43), ligesom der vel implicit lægges vægt på dette at udskrive livsfarlig medicin til en misbruger uden at have set og vurderet sidstnævnte.

Operativ fejlintervention var omdrejningspunktet i U 1998.1056 V. Sagen involverede to læger, som ved en kolostomi-operation fejlagtigt fremlagde nederste del af mavesækken i stedet for tyktarmen. Embedslægeinstitutionen havde i en indstilling til Sundhedsvæsenets Patientklagenævn anført, at der ved identificeringen af tyktarmen var udvist manglende omhu, hvorefter patientklagenævnet havde anmodet politiet om at rejse tiltale mod de to læger for overtrædelse af lægelovens $§ 18$. Ifølge sagsfremstillingen blev operationen udført af 1. reservelægen under vejledning fra overlægen, efter at sidstnævnte var tilkaldt på grund af komplicerede anatomiske forhold. Lægerne havde derpå i fællesskab først identificeret tyktarmen ved operationen, hvorpå 'den smuttede tilbage'. På grund af 'de meget stramme forhold', at patienten var 'pukkelrygget', og at der var svære betændelsesforandringer, lykkedes det først i et noget senere forsøg at få fremlagt og fastsyet et organ med henblik på stomi, som på baggrund af anatomi og 'spænding' formodedes at være tyktarmen. En uges tid efter operationen dukkede sonden, som var lagt ned i mavesækken, frem i stomiposen. Røntgen bekræftede, at det var mavesækken og ikke tyktarmen, der var lagt frem som stomi, hvorefter der blev foretaget fornyet operation. Patienten fik slutteligt tarmfunktion den normale vej. Den tiltalte overlæge beskrev, at »den foretagne operation var akut, idet patienten ellers ville have varet udsat for livsfare«. Patientklagenævnet fandt, at lægerne havde »undladt ved synets hjoelp at identificere, hvilken del af mave-tarmkanalen, de havde syet fast på underlivets forside«. Nævnet oplyste under sagen endvidere, at »tyktarmen har karakteristiske loengdeforløbende muskelstrøg $i$ vaggen (de såkaldte taenier), hvorved man kan identificere en rørstruktur som tyktarmen. Mavesakken har derimod en ensartet overflade. Derfor burde organforvekslingen vare undgået, selvom der var svar betcendelse og et kraftigt strcek«. Dertil tilføjedes, at »Er der imidlertid besvoer med at traeke tyktarm frem til stomi, er den korrekte fremgangsmåde, at man gør tarmen mere mobil gennem yderligere dissektion, hvor tarmen frigøres for strammende vaevsstrøg«. Sagen blev endvidere forelagt Retslægerådet, som ikke fandt 'undskyldende momenter' for 'fejltagelsen'. Ligeledes blev der til brug for sagen udfærdiget erklæring af en sagkyndig overlæge efter anmodning fra Den Almindelige Danske Lægeforening. Den sagkyndige konkluderede på baggrund af oplysningerne om »tarmslyng og dannelse af en stor byld«, samt dette at »organernes 
form og lejring var afvigende, måske på grund af patientens pukkelryggethed «, at de dermed følgende vanskelige omstændigheder formentlig sammenlagt kunne forklare, at »fejltagelsen kunne finde sted i forbindelse med det tredje fremtrcekningsforsøg af tarmen «. Den sagkyndige konkluderede sammenfattende, at det ikke kunne udelukkes, at »også andre kirurgiske kolleger med stor erfaring på dette område under scerligt vanskelige akutte forhold og til trods for scedvanlig omhu kunne komme til at begå samme fejl. Selv for den meget erfarne er større akutte operationer $i$ bughulen ofte endog sardeles vanskelige«. I byretten blev lægerne ved en domsmandsret fundet skyldige efter lægelovens $\S 18$, stk. 1, med baggrund i Retslægerådets erklæring og det ræsonnement, at det fra de tiltaltes side var »ubestridt, at der ved behandlingen af [patienten] blev begået loegelige fejl, idet patientens mavescek/tolvfingertarm blev lagt til stomi $i$ stedet for tyktarmen«. Efter anke til landsretten blev der igen afgivet vidneforklaring ved den sagkyndige. Han erklærede i landsretten i tilslutning til sit forudgående responsum, at »Vanskelighederne ved at identificere organerne $i$ bughulen beroede navnlig på den svare betondelsestilstand med beloegning på tarmene, hvorved konturerne må antages at vare blevet udvisket« og at »En yderligere dissektion som anført af Patientklagenovnet ville kunne medføre risiko for beskadigelse af blodkarrene med forbindelse til tyktarmen «. Landsrettens flertal fandt ikke, at de lægelige oplysninger i sagen gav et tilstrækkeligt sikkert grundlag for at anse den fejl, som lægerne havde begået i forbindelse med operationen, som en sådan fejl, at den kunne betegnes som 'grovere forsømmelse eller skødesløshed'. Lægerne blev herefter frifundet efter flertallet på 4, medens 2 voterende stemte for stadfæstelse af byretsdommen. Man finder ligesom i $\mathbf{U} \mathbf{1 9 8 3 . 1 0 9 3} \mathrm{V}$ en åbenbar normafvigelse. I denne sag bliver spørgsmålet om undskyldelighed dog fremtrædende. Det sandsynliggøres, at organerne under de angivne omstændigheder kan forveksles. Med hensyn til agtsomhedsvurderingen forekommer det desuden ubestridt, at der ifølge det oplyste var udfoldet store bestræbelser på at få operationen til at lykkes (herunder med tilkaldelse af ekstra ekspertise og gentagne forsøg på at afhjælpe patientens kirurgiske problemstilling), hvilken omstændighed turde levne sparsom plads til påstande om skødesløshed eller letsindighed.

Østre Landsrets dom TfK2007.371/2 handlede både om operativ fejlintervention og risikabel patienthåndtering med farlig medicin. I sagen havde en afdelingslæge behandlet en 16 årig mandlig patient med en sammenklappet lunge i skadestuen. Uden røntgenkontrol og stetoskopi indlagde han et dræn i brystkassens forkerte side. Endvidere havde han anvendt toksiske doser lokalbedøvelse, ligesom han også havde givet upræcise informationer om doserne til en tilkaldt narkoselæge samt angivet ukorrekte oplysninger om dosis i journalen. Patienten 
havde efterfølgende udviklet kramper. Lægen var som følge af sagen blevet suspenderet og havde senere opsagt sin stilling. Han udtalte til sit forsvar, at der var tale om »en svar patient, der skulle beroliges«, og at han derfor gav en større mængde lidokain (lokalbedøvelse) end normalt. Desuden angav han at være klar over, at der var en grænsedosis for forgiftning, men ikke vidste 'præcis, hvor den var'. Desuden havde han »tidligere talt med en loege, der havde mere forstand på det, og han havde sagt, at overgrcensen lå omkring $1.000 \mathrm{mg}$ «. Det fremgår videre, at lægen, inden han gik i gang, spurgte sygeplejerskerne, om nogen af dem havde været med til en sådan procedure tidligere. Det havde kun én af dem, »og det var mange år siden «. Normal dosis var efter det oplyste $200 \mathrm{mg}$, og det var lagt frem fra starten, og da lægen sagde, at han ville have 1.000, havde sygeplejersken sagt, at »det plejede de ikke at gøre«. Da han alligevel ville have 1.000 $\mathrm{mg}$, fik han det uden diskussion. I forbindelse med genanlæggelsen af drænet havde sygeplejerskerne spurgt, om de skulle tilkalde en bagvagt, hvilket han dog ikke fandt nødvendigt, »da der ikke var nogle tekniske problemer«. Lægen anførte til sagen, at han »regnede med, da der var gået ca. 11/2 time, at det meste af lidokainen var nedbrudt i kroppen«, og at det derfor »var forsvarligt at give 1000 mg igen, da det var nødvendigt at få bedøvet den pågceldende«. Lægen mente dog ikke at have brugt alt, hvad der var i sprøjten, »men han ville bruge det, der var nødvendigt «. Da patienten efterfølgende fik kramper, og der blev tilkaldt narkoselæge, fortalte lægen narkoselægen, »at han troede, at det måske skyldtes, at patienten havde fået for meget lidokain«, og at han havde givet $1.000 \mathrm{mg}$, fordi »det var det, han på det tidspunkt mente, at patienten havde i kroppen«. Den tiltalte læge erklærede, at han havde 'tabt hovedet'. Lægen blev af by- og landsret idømt bøde på $5.000 \mathrm{kr}$. for grovere skødesløshed. Landsretten bemærkede bl.a., at lægen havde gjort sig skyldig i 'to alvorlige fejl', nemlig det forkert anlagte dræn og anvendelsen af toksisk lidokain-dosis. Der påpeges således gentagne, men også hver for sig åbenbart konstaterbare normafvigelser (dræn stukket i brystkassens forkerte side og indsprøjtning af mangedobbelt forgiftningsdosis). Ligeledes tiltrækker agtpågivenhedselementet og skadespotentialet (herunder omfang, kausalitet og påregneligheden) sig opmærksomhed (»uden kontrol«; »toksiske doser«; »hvorefter patienten udviklede kramper«; »plejede ikke at gøre«).

U 1991.55 omhandlede risikabel patienthåndtering med farlig medicin. En sygeplejerske idømtes bødestraf på $1.500 \mathrm{kr}$. ved både by- og landsret efter den dagældende sygeplejerskelovs $\S 10$ om grovere forsømmelse eller skødesløshed ved fejlagtigt at have drejet narkoseapparatets doseringsgreb til maksimal dosering efter afslutningen af en operation. Patients blodtryk faldt, og på et tidspunkt 
holdt hjertet næsten op med at slå, hvorpå der blev iværksat hjertemassage, og patienten blev reddet. Byretten fandt, at sygeplejersken »alene var ansvarlig for betjeningen af halotanfordamperen, at hans indstilling af apparatet efter fødslen med henblik på lukning skete, uden at han ved direkte afloesning på doseringsskalaen forvissede sig om, at han faktisk lukkede for tilforslen af halotan, og at han først ca. 1 time efter fødslen ved en tilfceldighed konstaterede, at doseringsgrebet fejlagtigt var drejet til maksimal dosering «. Landsretten føjede hertil, at sygeplejersken »var alene ansvarlig for betjeningen af halotanfordamperen, så loenge den tilstedevarende ancestesiloege ikke fandt grundlag for indgriben i den normale procedure for tiltaltes opgave«. Der er i domsreferatet relativt få oplysninger om strafansvarsvurderingen. Selv om hændelsen på afstand kunne synes som blot et 'uheld', er og bliver det en åbenlys normafvigelse at opjustere livsfarligt bedøvemiddel til maksimum i stedet for at lukke helt. Agtsomhedsspørgsmålet synes adresseret ved konstateringen af, at tiltalte som eneansvarlig for doseringen ikke 'forvissede' sig om at have slukket. Den særlige uforsigtighed forekommer at skulle ligge i, at tiltalte så at sige har ageret i 'blinde'. Det forudsættes, at op,henholdsvis neddosering af patientens bedøvelse er en central opgave og særlig ekspertise for en narkosesygeplejerske og samtidigt står under dennes kontrol og ansvar. Se om 'Sygeplejerskers strafansvar' endvidere Jan Weidekamp i (U.1993B.468).

Den næste afgørelse, U 2011.1872/2Ø, drejede sig om manglende tilsyn og undersøgelse. En fødselsoverlæge blev idømt bøde på $10.000 \mathrm{kr}$. for overtrædelse af $\S 75$. Ifølge tiltalen havde han undladt personligt at tilse en gravid stærkt overvægtig kvinde indlagt med svære mavesmerter. Patienten var desuden blevet overmedicineret med morfin, idet en jordemoder ved en fejl havde doseret 200 mg morfin intramuskulært, hvorpå forvagten havde tilkaldt narkosen og institueret modgiftbehandling med naloxone. Efter forvagtens vidneforklaring havde hun i forbindelse med en umiddelbart påfølgende operation med kejsersnit orienteret bagvagten, som angiveligt blot havde sagt, at »at han var blevet orienteret, og at det skulle indberettes som en utilsigtet hoendelse«. Det fremgår af sagen, at patienten vejede over $200 \mathrm{~kg}$, og at hun efterfølgende fik et dødfødt barn, fik galdeblærebristning til bughinden og deraf følgende bughindebetændelse og chok og derpå selv afgik ved døden. Efter vidneforklaringen fra jordemoderen havde denne "gang på gang [bedt forvagten] om, at bagvagten skulle komme til stede«, medens forvagten havde fastholdt, at hun ville undersøge patienten først. Der var diskrepans med hensyn til det nærmere forløb omkring injektionen af morfin. Ifølge jordemoderen havde forvagten været til stede under injektionen, medens forvagten angav, at hun havde været tilkaldt til en anden patient. Desuden forkla- 
rede forvagten, at hun efterfølgende fik »den oplysning, at morfinen var givet« og "at [patienten] var faldet til ro, at kvalmen var vaek og opkastningerne var ophørt«. Ifølge sagsbeskrivelsen var der ikke bestilt tilsyn fra kirurgisk afdeling, og patienten var således heller ikke blevet vurderet af en speciallæge i kirurgi, herunder om anden behandling end smertebehandling (f.eks. et kirurgisk indgreb) var nødvendig. I retten blev der indkaldt en sagkyndig for Sundhedsstyrelsen, som om den almindelige ansvarsstruktur på hospitalsafdelinger angav, at »Ansvaret for en patient er $i$ realiteten hos den ledende overlage. Han kan ikke altid vare til stede og derfor delegeres ansvaret til bagvagten«. Det er værd at bemærke, at Sundhedsstyrelsens sagkyndige desuden slog fast, at »en overloge kan altid tillcegges et selvstcendigt ansvar for en opgave $i$ en afdeling - $i$ modscetning til en forvagt, der ikke kan tillagges et sådant selvstcendigt ansvar. Hvorledes fordelingen mellem bag- og forvagt er $i$ den enkelte afdeling, er meget afhoengig af, hvem det er, og hvordan den konkrete situation er.« Om ansvarsfordelingen udtalte han desuden, at »Hvis der sker noget på en vagt, så vil bagvagten efter hans opfattelse altid have et ansvar. Bagvagten vil typisk blive gjort ansvarlig og få en påtale, hvis det bliver til en klagesag«. Desuden fandt den sagkyndige, at »hvis man ikke kan finde en person at satte et ansvar på, vil det falde tilbage på den ledende overloege $i$ afdelingen. Hvis en forvagt har foretaget sig noget, uden at orientere eller taget kontakt til bagvagten, så vil bagvagten ikke nødvendigvis få en påtale, medmindre det bliver vurderet, at bagvagten burde have orienteret sig om, hvad der foregik $i$ afdelingen. «I relation til »generelle retningslinjer om forholdet mellem for- og bagvagter«, erklærede den sagkyndige bl.a., at bagvagten har »en pligt til at holde sig orienteret om patienterne $i$ afdelingen«. Endvidere udtalte han om den konkrete sag, at forvagten »havde varet $i$ afdelingen $i$ omkring 5 uger« og at »Det må give en forventning om, at forvagten har en meget begrcenset specialistviden«. Sagkyndige henledte desuden opmærksomheden på, at patienten var svært overvægtig, havde en galdestenslidelse, var gravid i 31. uge, og at patientens situation således var »en så kompliceret affore, at en forvagt og navnlig ikke en forvagt med den erfaring kunne komme $i$ norheden af at stille en korrekt diagnose«, idet »Det er og var en sag for en specialist«. Ifølge den sagkyndige burde bagvagten tilset patienten og »have varet mere opsøgende $i$ situationen«. Den sagkyndige henviste her til, at »det ikke [er] en hverdagsbegivenhed, at en patient på over $200 \mathrm{~kg}$ kommer ind på en fødeafdeling med galdestenssmerter«. Byretten fandt imidlertid ikke at have et »tilstrcekkelig sikkert grundlag for at fastslå, at tiltalte ved ikke personligt at have tilset hende tilsidesatte sine faglige pligter som ansvarlig overlage og bagvagt $i$ afdelingen på en så grov eller gentagen forsømmelig eller skødesløs måde, at han har overtrådt $\S 75[\ldots] \ll$. 
Opmærksomheden blev henledt på, at der f.eks. ikke forelå udtalelse fra Retslægerådet. Østre Landsret indhentede efterfølgende erklæring derfra og lagde i henhold til Rådets udtalelse til grund, at "forvagten ikke var specialist og havde begrcenset erfaring inden for området, og at forvagten konfererede med tiltalte vedrørende valg af smertestillende medicin til [patienten], men at tiltalte ikke tilså [patienten], heller ikke efter oplysning om, at hun var blevet fejlmedicineret med en overdosis af morfin«. Det bemærkedes, at patienten to dage senere afgik ved døden »som følge af svar betcendelse i galdeblaren med perforation til bughulen og bughindebetcendelse med heraf udløst choktilstand« samt at »at akutte mavesmerter hos en gravid kvinde krover vurdering af gyncekologisk/obstetrisk specialist og i de fleste tilfaelde tillige af abdominalkirurg, og at bagvagten under alle omstcendigheder burde have tilset [patienten], da forvagten ikke var specialist og havde meget begrcenset erfaring på området«. Flertallet i rådet havde videre fundet, at »bagvagten burde have tilset patienten og personligt sikret sig, at relevant observation og behandling blev institueret, da han fik oplysning om, at [patienten] var blevet fejlmedicineret med en overdosis af morfin«. Ifølge Retslægerådet var der tale om »en højrisikopatient på grund af samtidig graviditet, svaer overvaegt og kompliceret galdestenssygdom «, og efter rådets opfattelse var det således »en loegelig fejl«, at patienten ikke blev tilset af bagvagten. Med henvisning til Retslægerådets erklæring fandt landsretten, at »tiltalte ved under de givne omstcendigheder som bagvagt at have undladt at tilse højrisikopatienten har udvist grovere forsømmelse eller skødesløshed $i$ udøvelsen af sin virksomhed «. Straffen fastsattes, jf. autorisationslovens $\S 75$, til en bøde på $10.000 \mathrm{kr}$. med forvandlingsstraf af fængsel i 10 dage. Normafvigelsen bestod i den konkrete sag deri ikke som vagthavende fødselslæge at tilse en gravid kvinde i en åbenlys højrisiko situation (uforklarlige, svære, akutte mavesmerter, morfinforgiftning og ekstrem overvægt). Det er samtidig udtryk for en særlig mangel på agtpågivenhed (omhyggelighed) i den pågældende behandlingssituation ikke at have »sikret sig, at relevant observation og behandling blev institueret«. Skadespotentialet var uomtvistet, påregneligheden er tydeliggjort (højrisiko, ekstrem problemstilling) og årsagsforbindelsen med det manglende tilsyn forudsat.

Også Odense Byrets dom af 2. februar 2018 drejede sig om spørgsmålet om manglende tilsyn og undersøgelse. Den handlede om en overlæge på Odense Universitetshospital, som var tiltalt for overtrædelse af $\S 75$ (grovere eller gentagen forsømmelse eller skødesløshed), »idet han undlod at føre tilsyn eller lade en anden loege føre tilsyn på sine vegne, undlod at ordinere toet observation og undlod at lagge behandlingsplan for A, der som patient ca. kl. 6.10 samme dag var overført fra Intensiv afdeling $V$, og som-efter at vare fundet livløs på afdelingen 
$k l .15 .37$ - blev erklceret død $\mathrm{kl}$. 16.11«. Ifølge obduktionserklæringen døde patienten af metadonforgiftning. Sygeplejersken, som havde givet metadonen, erklærede sig umiddelbart skyldig i overtrædelse af autorisationsloven og betalte en bøde på 15.000 kroner. Anklagemyndigheden havde nedlagt påstand om bødestraf til overlægen. I første omgang var sigtelsen opgivet, da det ikke forventedes, at lægen kunne kendes skyldig. På foranledning af Styrelsen for Patientsikkerhed blev denne afgørelse imidlertid omgjort og sagen genoptaget. Om hændelsesforløbet blev det oplyst, at patienten var blevet indlagt med alkoholforgiftning og efter indtag af euforiserende stoffer. Et i sagen fremlagt diagram vidnede om en stabil patient. Styrelsens sagkyndige, som i øvrigt angav ikke at have kendskab til hverken dagældende instrukser eller retningslinjer, konstaterede hertil (lettere retrospektivt), at en patient ikke er stabil, når han efterfølgende 'findes livløs'. Ligeså er det værd at bemærke, at styrelsen fandt, at »Det er overlaegens ansvar, at en patient observeres«. Afdelingens administrerende overlæge beskrev som vidne, at »Når eller hvis der er tid, tilses de mindre hastende patienter. Det er sygeplejersken, der vurderer, hvem der skal have stuegang. Sygeplejerskerne er logens øjne og ører«, og føjede hertil, at »En grøn patient skal under en weekendvagt på et tidspunkt tilses af lagen, også uden sygeplejersken har bedt om det, men det er ikke en hasteopgave. Lagerne prioriterer ud fra afrapporteringen [...] og $i$ øvrig på baggrund af sygeplejerskens observationer«. Det kunne ifølge byretten efter bevisførelsen lægges til grund, at overlægen af sin yngre lægelige kollega havde fået at vide, at patienten, som nu var overflyttet til en almindelig patientstue, "var stabil og skulle udskrives senere samme dag [...] når han havde sovet den $u d \ll$. Det fremgår desuden, at der den pågældende lørdag var 'meget travlt'. Overlægen var den eneste læge på afdelingen og blev også kaldt til andre afdelinger, og det stod således klart, at overlægen »ingen pauser havde, inden han blev kaldt til forsøg på genoplivning af patienten«. Ved en gennemgang af instruksen fremgik det endvidere, at overlægen i tilfælde af en grøn patient skulle 'orienteres efter behov', og at plejepersonalet skulle observere patienten mindst tre gange i døgnet. Ifølge sygeplejerskejournalen, var patienten blevet tilset $\mathrm{kl}$. $11.07 \mathrm{i}$ forbindelse med sygeplejerskens medicinordination, og efter bevisførelsen blev det lagt til grund, at overlægen »hverken blev involveret $i$ ordineringen eller $i$ øvrigt af sygeplejersken blev bedt om at tilse patienten«. Byretten lagde derpå til grund, at overlægen havde handlet i overensstemmelse med de dagældende retningslinjer på afdelingen, og da overlægen allerede efter bevisførelsen ikke havde haft grund til at handle som beskrevet i tiltalen, blev han frifundet. Således udtalte byretten, at »strafansvar for undladelser må kraeve, at tiltalte har haft en grund til at handle«, men at »det efter bevisførelsen ikke [var] godtgjort, at der skulle have 
foreligget et sådant grundlag«. Således kan der i hændelsesforløbet ikke identificeres nogen situationel normafvigelse, ligesom det volder problemer at identificere tegn på manglende agtpågivenhed. Hændelsesforløbet bærer først og fremmest præg af en presset sundhedsorganisation med få ressourcer både lægemæssigt og med hensyn til sygeplejefaglig modtagelse, observation mv.

\section{Svendborgsagen}

Højesterets dom i U 2018.2073 H passer ikke umiddelbart i de ovenstående kategorier (manglende undersøgelse og tilsyn, farlig medicin, operativ fejlintervention m.m.). Den handlede om behandlingen af en patient med mavesmerter, som blev indlagt på en Fælles Akutmodtagelse (FAM), Odense Universitetshospital (OUH) i Svendborg. Patienten havde desuden sukkersyge og konstateredes efter timers forværring på sengeafsnittet alt for sent hypoglykæmisk (lavt blodsukker), udviklede hjerneskade og afgik senere ved døden. Patientombuddet havde, som der henvises til i højesteretsdommen, i første omgang truffet afgørelse i sagen med kritik af OUH. Patientombuddet havde i sin afgørelse vurderet, at »man burde have stoppet den vanlige sukkersygemedicin og målt As blodsukker ved indlaeggelsen og derefter 5-6 gange i døgnet samt ordineret og givet insulin og sukkervand afhoengig af blodsukkervardien ved disse målinger. Dette burde have varet påbegyndt i forbindelse med indloeggelsen«. På den baggrund fandt Patientombuddet, at »den behandling, som A modtog den 5. august 2013 på falles akutafsnit, Odense Universitetshospital, var under normen for almindelig anerkendt faglig standard «. I byretten frifandtes forvagten og en bagvagt for anklagemyndighedens påstand om overtrædelse af $\mathrm{AL} \S 75$. Østre Landsret frifandt bagvagten, men fandt forvagten skyldig og fastsatte en bødestraf på $5.000 \mathrm{kr}$. (se også (Birkeland, 2018)). I Højesteret blev forvagten frikendt. Nedenfor centreres opmærksomheden om forvagten.

Det fremgår i sagen af journalmateriale og vidneforklaringer, at patienten ved ankomst til FAM ikke var akut medtaget, men ligesom i Odense-sagen 'triageret grøn', og at mavesmerterne i døgnet op til indlæggelsen havde "varet en smule forvarret«, men ved ankomsten til sygehuset var »på samme niveau, som de havde veret $i$ de seneste måneder «. Om konteksten fremgår det, at patienten, grundet den langvarige problematik med intermitterende mavesmerter, var sat til CTscanning som led i en bredere udredning, og at indlæggelse fandt sted i regi af kirurgisk - og ikke medicinsk - afdeling. Det fandtes i journalen endvidere dokumenteret, at forvagten var opmærksom på sukkersygen, tillige med at patienten indtil videre skulle fortsætte sin 'vanlige' behandling, hvilket på indlæggelses- 
tidspunktet inkluderede selvadministrerede insulininjektioner i henhold til forudgående blodsukkermåling.

På hændelsestidspunktet var der en instruks for Svendborg Sygehus, dateret 21. september 2010, om 'Håndtering af indlagte diabetespatienter', hvori der stod følgende: »Patienter med erkendt diabetes indlagt med anden lidelse: Mange patienter vil vare fuldt $i$ stand til at varetage egen diabetesbehandling under indlaggelsen. Der anbefales til vurdering af diabeteskontrollen: B Blodglukose $x 8 i$ mindst et døgn • HbAlc. Ved markant forhøjede blodglukosevcerdier (typisk over $15 \mathrm{mmol} / \mathrm{l}$ ) eller HbAlc (over $10 \%$ ) eller ved skønnet behov udbedes tilsyn fra diabetesafdelingen [...]《. Ifølge vidneudsagn var det på hændelsestidspunktet 'fast procedure' på FAM, at plejepersonalet skulle sikre blodsukkermåling på alle nyindlagte patienter, når »der var en viden eller mistanke om sukkersyge«. Det står af vidneudsagn desuden klart, at der er og var fast praksis for, at plejepersonalet selv tager kontakt til vagthavende læge ved unormale måleresultater. Da der, jævnfør journalen, var viden om sukkersyge hos patienten, angav forvagten at have mindet plejepersonalet om behovet for blodsukkermåling, jf. FAM rutine, efter at have konstateret at blodsukker manglede. Vidnet fra plejesiden kunne imidlertid ikke huske noget derom, og påmindelsen fandtes ikke dokumenteret, ligesom det naturligvis ikke fandtes journalført, at forvagten derpå tjekkede plejepersonalet efter. Forvagten forekom efter sit udsagn at have ageret $i$ en form for tillid til, at plejepersonalet handlede i overensstemmelse med lægeordination og de for FAM almindelige procedurer. Der var under sagen indbyrdes modstridende udsagn mellem vidner og mellem vidner og forvagten angående hvilken efterfølgende kommunikation der fandt sted og om hvad. Denne modstrid kunne journalføringen ikke bringer klarhed over. Forsinkelse af journalopdateringer ser imidlertid ud til at kunne have spillet ind. Ligeså fremgår det af vidneudsagn, at FAM-plejepersonalet lejlighedsvis ikke kunne nå at holde sig orienteret i journalen. Der blev under sagen bemærkelsesværdigt henvist til manglende ressourcer/tid, og at der ikke fandtes nogen 'generel instruks' herom. Uagtet at Sundhedsvæsenets Disciplinærnævn på dette punkt har fastsat retningslinjer, hvorefter plejepersoner har en pligt til at »orientere sig i journalen om patientens sygdomme og behandling" som ikke kun omfatter »den sygdom og behandling, som har ført til den aktuelle indlcoggelse på afdelingen, men også andre sygdomme, som patienten er $i$ vanlig medicinsk behandling for under indloeggelse" (Sundhedsvæsenets Disciplinærnævn, 2012). Under alle omstændigheder var plejepersonalet efter deres udsagn ikke opmærksomme på patientens sukkersyge fra journal m.m., for i modsat fald ville de formentlig have sikret blodsukker. 
Byretten fandt samlet, at med forvagtens »anmodning til sygeplejersken om at foretage rutinemoessig blod sukkermåling, og ved ordinationen af 'cont. vanlig medicin', ville [patienten] få målt sit blodsukker hyppigt, dels ved måling af sygeplejersken efter loegeundersøgelsen [...] og dels ved den scedvanlige morgenmedicin, et interval på ca. 4 timer«, og forvagten kunne således berettiget forvente blodsukkermålinger af en sådan hyppighed. Under disse omstændigheder fandt byretten ikke, at der var udvist grovere forsømmelse eller skødesløshed.

Dommen blev af anklagemyndigheden anket til Østre Landsret med påstand om domfældelse efter anklageskriftet. Landsretten lagde Retslægerådets besvarelse til grund, hvorefter »der med de oplysninger, som [forvagten] var i besiddelse af om [patienten], burde have varet foretaget blodsukkermålinger med timers mellemrum, og at hun som den ansvarlige forvagt burde have haft fokus på laboratoriesvarene«, og at det ikke kunne føre til en anden vurdering, »at hverken bagvagt eller andre sundhedspersoner reagerede på oplysningerne $i$ journalen om [patientens] diabetes og på de manglende oplysninger om hans blodsukkerniveau«. Ligeledes henledte landsretten opmærksomheden på en skrivelse fra Sundhedsstyrelsen (hvormed landsretten formentlig mente Styrelsen for Patientsikkerhed) til politiet, hvori det blev beskrevet som »basal lagefaglig viden, at patienter med insulinbehandlet sukkersyge, mavesmerter og kvalme er i risiko for at udvikle for højt eller for lavt blodsukker«, og at »for lavt blodsukker er en livstruende tilstand«. På denne baggrund sluttede landsretten, at forvagten »med den fornødne tilregnelse har gjort sig skyldig i overtrcedelse af lov om autorisation af sundhedspersoner $\S 75[\ldots]$ [... Uagtet at fokus her er på straffesagen mod forvagten, aner man i landsrettens ansvarsvurdering en ikke særlig nemt forklarlig uoverensstemmelse. Uanset den beskrevne almindelige praksis, instruksgrundlaget på FAM og de generelle betragtninger om 'basal lægefaglig viden' finder landsretten, at forvagtens ageren var udtryk for grovere forsømmelse, medens sukkersyge hos en patient, som den i sagen omhandlede, med henvisning til byrettens argumentation på den anden side blot blev henført til et blandt »alle delaspekter af en patients ikke-kirurgiske sygdomme«, som det ikke kan forventes, at en kirurgisk bagvagt 'kender' og adresserer. Det findes i øvrigt ikke oplyst, hvorfor anklagemyndigheden derpå opgav tiltalen mod bagvagten, endskønt anklagemyndigheden på baggrund af $\mathbf{U}$ 2011.1872/2 Ø (samt den i ovenomtalte Odense-sag anlagte linje) skulle forventes at have et særligt fokus på netop bagvagtens overordnede ansvar og tilsynsforpligtelse.

Østre Landsrets dom blev anket til Højesteret af forvagten med påstand om frifindelse, subsidiært hjemvisning til landsretten og mere subsidiært strafbortfald eller formildelse af straffen. Anklagemyndigheden påstod skærpelse og anlagde 
nu en bemærkelsesværdigt mere teknisk-faglig kurs med henvisning til bl.a. forløbet af mavesmerternes intensitet og den såkaldte 'VAS'-skala. Endvidere udtaltes, at forvagten "vvar bekendt med, at [patienten] havde haft en enkelt slimet opkastning og havde vaeret mere forkvalmet«. Således burde hun i henhold til anklagemyndigheden, da hun var opmærksom på, at patienten var kendt med insulinkrævende sukkersyge, have været »ekstra opmoerksom på at laegge en plan for kontrol af hans diabetes og have sikret sig, at hans blodsukker rent faktisk blev målt«. Anklagemyndigheden påstod herpå, at det 'derfor' var »en åbenbar fejl, at hun i journalen ordinerede, at [patienten] skulle fortscette med sin scedvanlige medicin, herunder diabetesmedicin, når hun ikke havde sikret sig, at hans blodsukker var blevet målt«. Anklagemyndigheden argumenterer desuden ud fra, at »Det forhold, at hun mundtligt anmodede den modtagende sygeplejerske B om at måle [patientens] blodsukker, viser, at hun var opmarksom på, at det var vigtigt at have fokus på hans blodsukker«. Og ikke mindst argumenteredes, at patientens »tilstand med mavesmerter, kvalme, opkastning og insulinbehandlet diabetes indebar, at han ikke var en af de patienter, der ifølge sygehusets diabetesinstruks selv kunne varetage egen diabetesbehandling under indloggelsen«. Anklagemyndigheden synes hermed direkte at slutte som noget selvfølgeligt, at sukkersygepatienter med kvalme og mavesmerter ikke er i stand til at håndtere deres sukkersygebehandling, men kræver professionel intervention. Afslutningsvis henviste anklagemyndigheden igen til styrelsens almindelige bemærkninger om den basale lægefaglige viden om sukkersyge, idet der tillige refereredes til Retslægerådets vurdering, at »der burde have voeret foretaget blodsukkermålinger med timers mellemrum, at man burde have haft fokus på laboratoriesvarene, og at der $i$ forbindelse med indlaggelsen burde have varet udarbejdet en plan for kontrol af diabetes« (jf. ovenfor). Anklagemyndigheden føjede hertil, at »det havde vaeret nemt for [forvagten] at mindske risikoen for skadens indtrceden, idet hun f.eks. blot kunne have indført i journalen, at As blodsukker skulle måles, ligesom hun blot kunne have fulgt op på, om hendes instruks var blevet efterlevet. Det manglende journalnotat om, at hun ved indloggelse af [patienten] mundtligt havde bedt [sygeplejersken] om at måle [patientens] blodsukker, medfører ikke i sig selv, at hun har udvist grovere forsømmelse eller skødesløshed i autorisationslovens $\$ 75$ forstand. Den manglende journalindførelse medfører dog sammen med de øvrige fejl, som Thar begået, at hun ud fra en samlet betragtning har udvist grovere forsømmelse eller skødesløshed."

Om Styrelsen for Patientsikkerheds forståelse af instruksen hedder det i højesteretsdommen, at »alene patienter med et stabilt blodsukker kan varetage egen diabetesbehandling under indloeggelsen. Patienter med insulinbehandlet sukker- 
syge, mavesmerter og kvalme, har øget risiko for at udvikle for højt eller for lavt blodsukker, da de ikke kan spise regelmaessigt, som det var tilfceldet med [afdøde]. [afdøde] var med sit sygdomsbillede med insulinbehandlet sukkersyge, mavesmerter og kvalme ikke egnet til, at skulle varetage egen diabetesbehandling, som det også blev understreget ved retsmødet.« Med hensyn til instruksens nærmere udfærdigelse vil den nøjeregnende måske hæfte sig ved, at der netop ikke står, at 'der anbefales vurdering af diabeteskontrollen'. Derimod er fastsat en fælles retningslinje for, hvordan en vurdering af diabeteskontrollen kræver såvel multiple (8) blodsukker-målinger som HbAlc (i modsætning til andre mulige regimer, så som x 6 dagligt som foreslået af Retslægerådet). Fortolkes instruksen derhen, at der er tale om en generel (automatisk) anbefaling om vurdering af diabeteskontrollen, synes logikken med en særskilt omtale i instruksen af patienter indlagt med anden lidelse at bortfalde. Vælger man alligevel denne fortolkning, fremgår det stadigvæk ikke, om instruksen skulle opstille et krav om akut forvagtsordination umiddelbart ved ny-indlæggelse af også upåvirkede patienter. Eller om det er en standard til brug i den videre udredning iværksat under stuegang og f.eks. efter gennemgang på umiddelbart forestående morgenkonference. Instruksens værdi som norm-fastsætter mindskes således, hvorefter de stedlige kutymer for konkret patienthåndtering jf. vidneudsagn træder i forgrunden.

Højesterets flertal lagde efter landsrettens bevisresultat til grund, at forvagten mundtligt bad sygeplejersken om at måle patientens blodsukkerværdi efter samtalen med patienten, og at det endvidere må antages at, forvagten ")ved at ordinere, at [patienten] skulle fortscette med sin scedvanlige medicin, kunne forvente, at han - ud over den blodsukkermåling, hun konkret havde anmodet [sygeplejersken] om at foretage - ville få målt sit blodsukker i forbindelse med den saedvanlige morgenmedicin ca. 4 timer senere«. Dertil fremdrog flertallet, at samtlige sundhedspersoner med tilknytning til akutmodtagelsen på Svendborg Sygehus under hovedforhandlingerne i by- og landsret i al væsentligt samstemmende havde forklaret, at »samarbejdet mellem loeger og sygeplejersker byggede på en foelles forståelse om, at sygeplejersken kontaktede logen, hvis der måltes påfaldende vardier ved undersøgelser «. Det konkluderedes af flertallet slutteligt, at forvagten ikke havde »handlet med en sådan høj grad af uagtsomhed, at det kan betegnes som en grovere forsømmelse eller skødesløshed «, hvorfor det stemte for frifindelse. Højesterets mindretal tog derimod udgangspunkt i, at forvagten ordinerede, at patienten skulle fortsætte med sin vanlige medicin, inklusive insulin, »uden at hun ordinerede hyppige blodsukkermålinger, uden at hun lagde en plan for, hvordan hans blodsukker skulle behandles, og uden at hun fulgte op på manglende blodsukkermålinger«, og henledte derpå opmærksomheden på spørgsmålet, 
»om disse forhold under de foreliggende omstoendigheder udgør en grovere forsømmelse eller skødesløshed, jf. autorisationslovens $\S 75$ «. Mindretallet bemærker endvidere, at forvagten ud over at bede en sygeplejerske om at måle patientens blodsukker »ikke gav nogen instruktion til sygeplejersker eller andre vedrørende behandlingen af [patientens] diabetes under indloeggelsen «, idet forvagten i øvrigt »efter sin forklaring ikke [var] ekstraordincert presset af opgaver i forbindelse med indlogggelsen af [patienten] «. Hvad denne instruktion nærmere skulle have gået ud på, fremgår ikke af mindretallets ræsonnement, men med en fornyet henvisning til de af styrelsen fremdragne behandlingsmæssige aspekter ved sukkersyge anfører mindretallet derpå, at det må »stå klart for enhver loege, at en insulinbehandlet diabetikers blodsukker ikke under indlaggelse på et sygehus på grund af manglende planlagning eller agtpågivenhed må kunne falde til et meget lavt niveau og forblive på et sådant lavt niveau $i$ så lang tid, at der kan opstå varig hjerneskade«. Mindretallet finder på denne baggrund, at forvagten 'som ansvarlig forvagtsloge' havde handlet »i strid med basal loegefaglig viden« og »udvist grovere forsømmelse, navnlig ved under de anførte omstcendigheder at undlade at laegge og instruere om en plan for behandlingen af As insulinbehandlede diabetes under hans indloggelse, herunder med henblik på at forebygge at meget lavt blodsukker kunne medføre risiko for varig hjerneskade«.

Når spørgsmålet om den tiltalte forvagts strafansvar skal afklares, bliver de centrale spørgsmål, a) om det kan konstateres, at forvagten $i$ den pågceldende situation, altså ved afslutningen af journaloptagelsen og planlægningen af den initiale patientbehandling i forbindelse med indlæggelsen, samt den videre ageren i forhold til patientværdier og patienttilstand over natten har udvist en afvigelse fra de faglige normer, som er af en størrelsesorden lig den gængse forståelse af $\S 75$. Med hensyn til sidstnævnte må skeles til den i retspraksis fastsatte linje (alment konstaterbar normafvigelse). Såfremt spørgsmålet besvares bekræftende, må det undersøges, om der skulle være undskyldende omstændigheder (jf. U 1998.1056 V). Af den tidligere retspraksis fremgår, at normafvigelsen så at sige har 'talt for sig selv' (fjernelse af forkert finger, drænindstik i forkerte lunge, fuldstændig undladelse af at tilse højrisikopatient, mangedoblet dosis farlig medicin, mv.). Identifikation af normafvigelse $i$ henhold til retspraksis om $\S 75$ kræver for så vidt ikke videre videnskabelig argumentation, konkret instruks fortolkning eller deslige.

For det andet er spørgsmålet, b) vurderingen af, om der $i$ den pågceldende situation for det første er udvist manglende agtpågivenhed. Og ifald dette spørgsmål besvares bekræftende, opstår spørgsmålet, om denne mangel på agtpågivenhed har en scerlig ('grovere' eller gentagen) karakter. 
Sidst skal det undersøges, c) om der i sagen kan konstateres en kausal og $p \stackrel{a}{a}-$ regnelig forbindelse mellem patientens letale hypoglykæmi og forvagtens konkrete ageren.

Med hensyn til normafvigelses-vurderingen under punkt $a$ ) må retten her støtte sig på kutymer, eksisterende instrukser og styrelsens fortolkning af disse samt på vurdering foretaget ved Retslægerådet. Det havde formentlig været kritisabelt slet ikke at instituere blodsukkermåling hos en patient kendt med sukkersyge. Men derfra forslår almindelige betragtninger om sukkersygens alvorlighed og om hvad der måtte være 'basal lægeviden' ikke, når det retrospektivt skal vurderes, hvad normen i den konkrete situationen tilsagde af handling. Det er ovenfor beskrevet, hvorledes fortolkningen af den på hændelsestidspunktet gældende instruks volder problemer, og at man næppe uden usikre mellemregninger kan nå frem til, at instruksen i situationen utvetydigt foreskrev umiddelbar tilsidesættelse af patientens egenkontrol med sin diabetesbehandling, suspendering af vanlige medicinske behandling med insulin mv., og igangsættelse af personalekontrolleret blodsukker, f.eks. hver fjerde time. Dette forekommer desuagtet at være Retslægerådets vurdering. Én ting er dog Retslægerådets vurdering af hvad der 'burde' have fundet sted. Noget andet er så, om der hvis 'burde'-vurderingen holder er tale om en normafvigelse jf. den i retspraksis anlagte linje. Og medens det for de fleste formentlig vil forekomme obligatorisk, at en sukkersygepatient med ikke-akutte mavesmerter får tjekket sit blodsukker under en sygehusindlæggelse (som forvagten angiveligt også havde foreskrevet), er det mere tvivlsomt, om den netop ovenfor skitserede udlægning af normerne for blodsukkermåling i situationer som Svendborgsagens har denne for almindelige mennesker åbenbare karakter. Medmindre man har de retrospektive briller på.

Derpå kommer spørgsmålet om forvagtens agtpågivenhed i den pågældende situation, $b$ ). Antager man, uagtet indvendingerne ovenfor, at forvagtens håndtering bryder med normerne, taler det $\mathrm{i}$ sagens natur for $-\mathrm{i}$ det mindste - en vis grad af uagtsomhed. Henholder man sig til formuleringen af $\S 75$, er det derimod spørgsmålet om denne uagtsomhed ligefrem afspejler en 'grovere eller gentagen forsømmelse eller skødesløshed'. Svaret herpå taler måske for sig selv, men fortjener ikke desto mindre en uddybning. Anklagemyndigheden foreslår en række handlinger, hvormed forvagten kunne have sikret sig i forhold til behandlingen af patienten. Væsentligt må det imidlertid være at vurdere, om en forvagt, som modtager og indlægger en ikke akut medtaget sukkersygepatient samt ordinerer vanlig medicin og standardprøver, tillige med tjek af blodsukker, og efterfølgende agerer i tillid til, at afdelingskutymer opretholdes, udviser 'grovere eller gentagen forsømmelse eller skødesløshed'. Det kan givetvis diskuteres, om forvagten i 
Svendborgsagen i situationen har udvist en sundhedsprofessionel adfærd, som lever fuldt op til, hvad faglige guidelines, videnskabelig litteratur, eller ekspertpaneler måtte tilsige, men at henføre denne diskussion til et spørgsmål om 'grovere eller gentagen forsømmelse eller skødesløshed' kan det, jf. ovenstående, blive sværere at finde holdepunkter for.

Med hensyn til c) kan indvendes, at der måske nok kan påstås en årsagsforbindelse mellem manglende ordination af multipel personaleudført blodsukker og patientens forløb. Adækvansen kniber det imidlertid med. Den forvagt, som hos en ikke-akut medtaget, bevidsthedsklar og 'erfaren' sukkersygepatient specifikt bestiller en blodsukkermåling, kan (og skal) vel næppe med rimelighed påregne, at den rutinerede sygeplejerske ikke derpå foretager blodsukkermålingen, at plejepersonalet ikke efterfølgende læser journalnotaterne, samt at patienten ikke dernæst tages imod med omklædning, diabetespleje og almindelig observation på afdelingen for sluttelig at gå i dødelig hypoglykæmisk koma.

Sidst kan ganske kort kommenteres på journalførings-aspektet, som påkaldte sig nogen interesse i medierne. Mht. journalføringen af påmindelsen til plejesiden om blodsukkermåling indgik dette moment ikke selvstændigt $i$ anklagen, hvilket kan skyldes det forhold, at anklagemyndigheden allerede tidligt har vurderet, at det ikke ville kunne bære straffesagen. Dette fremgår muligvis af udsagnet fra anklageren under højesteretssagen om at »Det manglende journalnotat [...] sammen med de øvrige fejl« ud fra en 'samlet betragtning' implicerer, at forvagten har udvist grovere forsømmelse eller skødesløshed. Med anklagemyndighedens udtalelser om, at forvagten »mundtligt anmodede den modtagende sygeplejerske B om at måle As blodsukker« og »blot kunne have fulgt op på, om hendes instruks var blevet efterlevet «, står det tilsvarende klart, at anklagemyndigheden ikke havde til sinds at gå nærmere ind i de bevismæssige forhold omkring den påståede påmindelse. Noget andet er, at retten må formodes at ville vurdere en modstrid (om denne mundtlige ordination vitterligt havde fundet sted) i tiltaltes favør.

\section{Fastlæggelse af sundhedspersoners strafansvar}

Ovenstående gennemgang påpeger et antal centrale temaer, som indtil nu har indgået i vurderingen af sundhedspersoners strafansvar, så som mangelfuld undersøgelse eller tilsyn, risikabel patienthåndtering med farlig medicin, vaesentlig operativ fejlintervention (f.eks. forkerte side), samt anvendelse af ulovlig intervention. Den relativt hyppige forekomst af uenighed mellem by- og landsretter indikerer, at niveauet for sundhedspersoners strafansvar ligger i 'omegnen' af de gennemgåede sager, og overordnet synes $\S 75$ først og fremmest at finde anven- 
delse, når enkeltpersoner har udvist substantielt afvigende sundhedsprofessionel adfcerd. Under alle omstændigheder forudsættes det, at sundhedspersonen var tilregnelig (sammenhold Waaben (Waaben, 2015)). I tråd med strafferetlig teori lægges der vægt på såvel tilstedeværelsen af en situationel, alment konstaterbar og ikke-undskyldelig normafvigelse (det objektive element), hvor gentagelsestilfælde vil spille ind (§ 75's ordlyd og U 1987.608). Domstolenes placering af normafvigelsens 'signifikansniveau' ved det alment konstaterbare tilgodeser de i forarbejderne til strafbestemmelsen beskrevne hensyn, at sundhedspersonen ikke behøver at frygte for at blive draget til ansvar, når blot denne »holder sig indenfor, hvad hans videnskabelige Uddannelse, Erfaring og sunde Fornuft tilsiger ham « (se lovbemærkningerne til lægelovens $\S 18$, Rigsdagstidende 1931-32, tillæg A, sp. 4036-4037). Barren er lagt relativt højt, ved graverende handlingsafvigelser, som udtrykker decideret 'Ukyndighed, Skødesløshed eller Letsindighed' og som klart overgår 'mindre Forseelser'. Samtidig imødekommes i betydeligt omfang risikoen for at straffe sundhedsprofessionel virksomhed, som reelt afspejler den almindelige variation inden for klinisk beslutningstagning eller efterfølgende måtte vise sig at være korrekt (sammenlign de 'loegevidenskabelige Fremskridt'). Men placeringen af signifikansniveauet betyder samtidig, at sundhedspersoner vil kunne straffes ved domstolene, når deres ageren ikke kan »staa for en faglig« og (almen-) »menneskelig Kritik«. Nedslaget ved det alment konstaterbare (eller hvad der for almindelige mennesker må forekomme åbenbart) markerer, endskønt også afgrænsningen heraf konkret vil kunne give anledning til diskussion, et betydningsfuldt pejlemærke for diskussionens rammer. Samtidig overlades det til sundhedsmyndighederne at føre tilsynet med de mindre forseelser (som vil kunne være knapt så åbenbare og have mere specialfaglig, teknisk karakter) og om nødvendigt i disse tilfælde udtale deres 'Misbilligelse' eller give 'en Tilrettevisning' med henvisning til kravet om sundhedsprofessionel 'omhu og samvittighedsfuldhed' (AL § 17). Til forudsætningen om alment konstaterbar og ikkeundskyldelig normafvigelse føjer sig en ('subjektiv') betingelse om scerlig uforsigtighed (manglende agtpågivenhed, modsat hændelighed) eller overlæg. Således fastholder formuleringen af autorisationslovens $\S 75$ (ligesom 'omhu og samvittighedsfuldhed' i lovens $\S 17$ ) betydningen af professionsansvarets 'subjektive' side i forhold til den beskrevne, mere 'objektivt' iagttagelige fravigelse fra almindelig anerkendt faglig handlemåde (norm). Når der skal være tale om minimum en scerlig uforsigtighed, undtages de påviselige, men mere 'jævne' afvigelser fra, hvad der regnes for almindeligt anerkendt faglig adfærd, som imidlertid kan give disciplinærnævnspåtale. Dertil kommer et skadespotentiale, som skal være væsentligt, stå i sandsynlig årsagsforbindelse med handlingen (eller undla- 
delsen) og konkret måtte skulle tages i betragtning som mulighed (påregnelighed, sammenhold Waaben (2015); 'inter-subjektivt' element). Selv om det erkendes, at der kan være en flydende overgang mellem ovenstående elementer i strafansvaret, må det sammenfattende konstateres, at bestemmelsen i $\S 75$ i sammenhæng med retspraksis og strafferetsteori anviser nogle ganske tydelige konturer af det sundhedsprofessionelle strafansvar.

\section{Litteratur}

Birkeland, S. Lægegerning og strafansvar. Dagens Medicin, 5. marts 2018.

Eyben, B.V., \& Isager, H. Larebog i erstatningsret. Jurist- og Økonomforbundet, København, 2015.

Hedegaard, A. 2018. »Det er en frifindelse, men ikke en klar dom«. Ugeskr Laeger, 28. marts 2018.

Hildebrandt, S. 2018. Jurist: Frifindelse i Svendborgsag sikrer ikke læger fremadrettet. Dagens Medicin, 3. april 2018.

Sundhedsvæsenets Disciplinærnævn. Sammenfatning af nævnets praksis vedrørende medicinhåndtering i sygeplejen 2009-2012. Praksissammenfatning. København, 2012.

Waaben, K. Strafferettens almindelige del. Bind 1. Ansvarslceren, Karnov Group, København, 2015. 